\title{
New species of Thaumastus from Lagoa Santa region, Minas Gerais State, Brazil (Mollusca, Gastropoda, Pulmonata, Bulimuloidea) ${ }^{1}$
}

\author{
Meire Silva Pena ${ }^{2,3}$, Norma Campos Salgado² \& Arnaldo C. dos Santos Coelho ${ }^{2}$
}

1. Contribution number 81, Malacologia, Departamento de Invertebrados, Museu Nacional, Universidade Federal do Rio de Janeiro.

2. Museu Nacional, Quinta da Boa Vista, s.n., São Cristóvão, 20.940-040 Rio de Janeiro, RJ, Brasil. (nsalgado@pfe.microlink.com.br); (malacomn@mn.ufrj.br)

3. Instituto de Ciências Biológicas e Saúde, Pontifícia Universidade Católica de Minas Gerais, Av. Dom José Gaspar, 500, 30.535-616 Belo Horizonte, MG, Brasil. (mpenapuc@pucminas.br)

ABSTRACT. A new species of Thaumastus (Thaumastus) Martens, 1860, from Minas Gerais State, Brazil, is described and illustrated, based on the morphology of the shell, jaw, radula and soft parts.

KEYWORDS. Bulimulidae, morphology, taxonomy, Thaumastus sp. nov., Thaumastus (T.) taunaisii.

RESUMO. Nova espécie de Thaumastus da região de Lagoa Santa, Minas Gerais, Brasil (Mollusca, Gastropoda, Pulmonata, Bulimuloidea). Uma nova espécie de Thaumastus (Thaumastus) Martens, 1860, do Estado de Minas Gerais, Brazil, é descrita e ilustrada, com base na morfologia da concha, mandíbula, rádula e partes moles.

PALAVRAS-CHAVE. Bulimulidae, morfologia, taxonomia, Thaumastus sp. nov., Thaumastus (T.) taunaisii.

Thaumastus Martens, 1860 was described as a subgenus of Bulimulus Leach, 1814, with Bulimus hartwegi Pfeiffer, 1846 as the type species.

Strebel (1910) described the six subgenera in Thaumastus based on sculpture of the protoconch while ZILCH (1960) and BREURE (1979) provided data on shell and soft parts. At present, fifty seven species are recognized. The shell of the species in this genus is relatively large, oval-elongated, brownish, mostly with axial streaks and spiral light bands, suture impressed and aperture oval or ear-shaped with thick peristome. In addition, the presence of a columellar callus, expanded or not, with rectilinear or rounded contour is an additional character which helps identify these species.

The Brazilian species Thaumastus (Thaumastus) taunaisii (Férussac, 1822), T. (T.) magnificus (Grateloup, 1839), T. (T.) achilles (Pfeiffer, 1852), T. (T.) baixoguanduensis Pena, Coelho \& Salgado, 1996 and T. (T.) tiradentensis Pena, Coelho \& Salgado, 1996 have been studied, characterized and described by JURBERG et al. (1979, 1988), Barros et al. (1991), Salgado \& Coelho (1995), Salgado et al. (1995) and Pena et al. (1996). These studies provide us with grounds to propose a new species based on material from Lapinha Cave, Lagoa Santa municipality and from Lapa Vermelha, Pedro Leopoldo municipality, Minas Gerais State, Brazil. We also aim to recharacterize morphologically the subgenera of Thaumastus providing a basis for further analyses of the genus.

\section{MATERIAL AND METHODS}

The material studied consists of shells and specimens deposited in the Mollusks Collections of Museu Nacional, Universidade Federal do Rio de Janeiro, Rio de Janeiro (MNRJ), Museu de Zoologia de São Paulo,
Universidade de São Paulo (MZSP), Brazil and Zoologisches Museum der Universität Hamburg (ZMH), Germany.

The identification was done by comparison with type material and adult shells deposited in MNRJ and MZSP, Brazil; The Academy of Natural Sciences of Philadelphia (ANSP), Philadelphia, USA; Forschungsinstitut und Naturmuseum Senckenberg (SMF), Frankfurt and Museum für Naturkund der Humboldt-Universität (MNHU), Berlin, Germany; The Natural History Museum (BMNH) London, U.K.; and/or original descriptions and illustrations. The terminology used for protoconch description followed STREBEL (1910).

The morphology of shell, jaw, radula and reproductive system was based on the methods used by Jurberg et al. (1988) and Salgado \& Coelho (1995). Photographs were taken with a digital camera and electronicmicrographs on S.E.M. Colors were codified according to KüPPERS (1979).

\section{Thaumastus (Thaumastus) lundi sp. nov. (Figs. 1-15)}

Diagnosis. Shell oval-elongated, $61 / 8-7$ whorls; protoconch with wide and depressed nucleus, 21/2-3 whorls; aperture ear-shaped. Radula with 32 lateral teeth in one transversal row and jaw with 15-17 plates. Ovariotestis with six follicle groups; phallus retractor muscle wide and pleated, attached to the proximal part of flagellum; deferent duct emerging on the same level as the bifurcation of bursa duct and free oviduct running over and then under the muscular sheath, making a narrow loop and returning attached to the phallus.

Description. Shell (figs. 1, 2) relatively large, ovalelongated, very thick with yellowish-brown (KüPPERS, 1979, $\mathrm{N}_{50} \mathrm{~A}_{70} \mathrm{M}_{40}$ ), not umbilicated, truncated apex, with $61 / 8-7$ 
1/4 convex whorls. Protoconch (fig. 3) with 21/2-3 whorls, wide and depressed nucleus with oblique striae slightly undulated and anastomosed from the second whorl. Teleoconch with thick lines, and with wide and narrow axial reddish-brown (KüPPERS, 1979, $\mathrm{N}_{60} \mathrm{~A}_{70} \mathrm{M}_{90}$ ) bands irregularly alternated; periostracum thin, shiny and adhered. Convex body whorl with a spiral, dull lightyellowish band, slightly crenulated suture. Aperture earshaped, slightly shorter than half the total height of the shell; superior area of outer lip forming a small angle with parietal margin; thick and whitish peristome, not reflected; thick columellar callus. Measurements (mm) (25 shells of type-series): total height (h: 71-84); width (w: 26-32); height and width of aperture (ha: 27.4-36.75, wa: 18.05-19.15).

Jaw (fig. 4) presenting 15-17 irregular and juxtaposed plates, more pigmented on the extremities. Radula (figs. 5-7) with 32 lateral teeth on each half of transversal row. Central tooth with trapezoidal base, median and lateral cusps rounded with partial symmetry. On the lateral teeth, beginning from the $\mathrm{L}_{1}$, one of the lateral cusps becomes progressively more pointed than the other. The $\mathrm{L}_{7}$ shows maximum asymmetry.

Soft parts. Roof of palial cavity (fig. 8) strongly pigmented with a vascular dense net, kidney grayishbrown, almost triangular; pericardium corresponding in size to kidney face where it is located. Reproductive system (figs. 9-15): ovariotestis consisting of six follicle groups varying in size; long and strongly folded hermaphroditic duct variable in diameter, more pigmented in proximal region near the albumen gland; fertilization complex embedded in the concave face of albumen gland, presenting elongated and curved free extremity; voluminous, translucent-white to milky-white albumen gland with rounded free extremity; uterus wrinkled and whitish; prostate with granulose aspect; bursa duct with unilateral constriction, and globose bursa copulatrix in its extremity; long free oviduct without folds; short vagina; deferent duct appearing on the same level as the bifurcation of the oviduct with the bursa duct, running externally adhered to the free oviduct region, going up and down the muscular sheath, bending and forming a narrow loop, then running along the penian complex as far as the proximal region of the epiphallus and toward its interior. Penian complex (fig. 11) consisting of a wide and pleated retractor muscle attached to the short flagellum; epiphallus long; phallus four times the length of the epiphallus and flagellum together. Histological and microanatomically, this complex shows diverse areas that present longitudinal muscular epithelium folds (pilasters), glandular masses, muscular layers and different positions of the deferent duct lumen. Flagellum (fig. 12) consisting of unilateral group of longitudinal and low folds and eccentric-elongated lumen. Epiphallus (figs. 13, 14) with low pilasters and ample lumen in the distal region, two glandular masses and lumen located in the basal region. Phallus (fig. 15) presenting high pilasters in both apical and median regions as well as low pilasters in the basal region with spermatozoid masses filling the wide lumen. The muscular septum separates, partially, the epiphallus from the phallus areas.
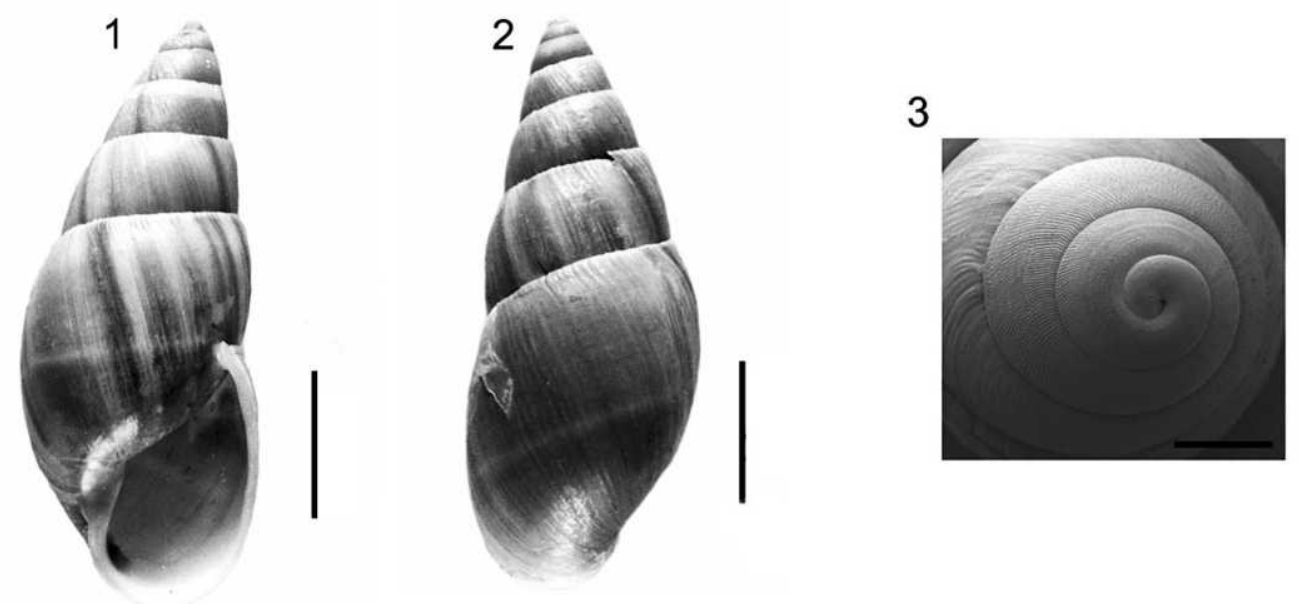

5

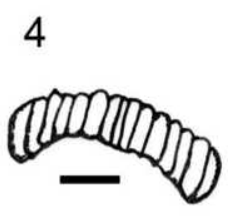

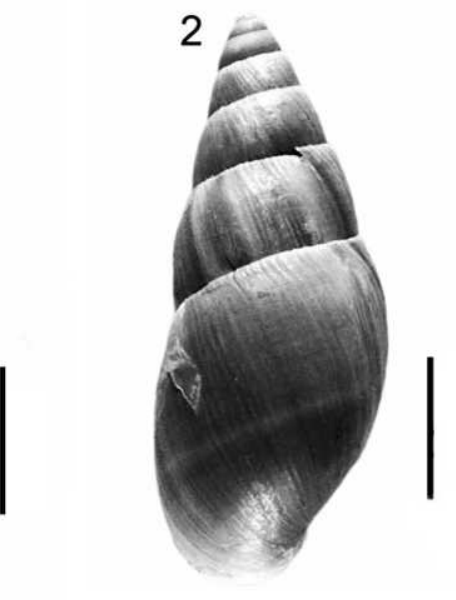

6

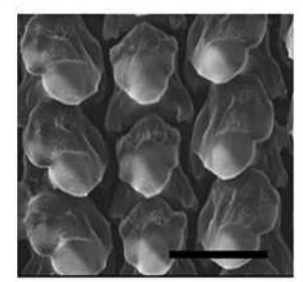

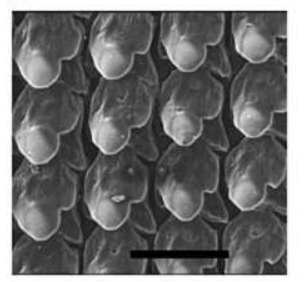

7

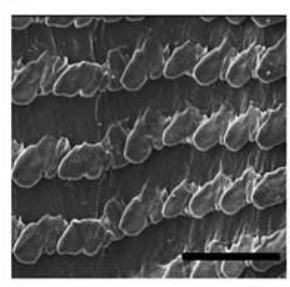

Figs. 1-7. Thaumastus (Thaumastus) lundi sp. nov. Shell, holotype, MNRJ 8092: 1, ventral view; 2, dorsal view (scale bar, 2 cm). Paratype, MNRJ 9807: 3, protoconch (scale bar, 0,16 mm); 4, jaw (scale bar, 10mm). Radula: 5, central tooth; 6, lateral teeth; 7, marginal teeth (scale bar, $78 \mu \mathrm{m})$. 

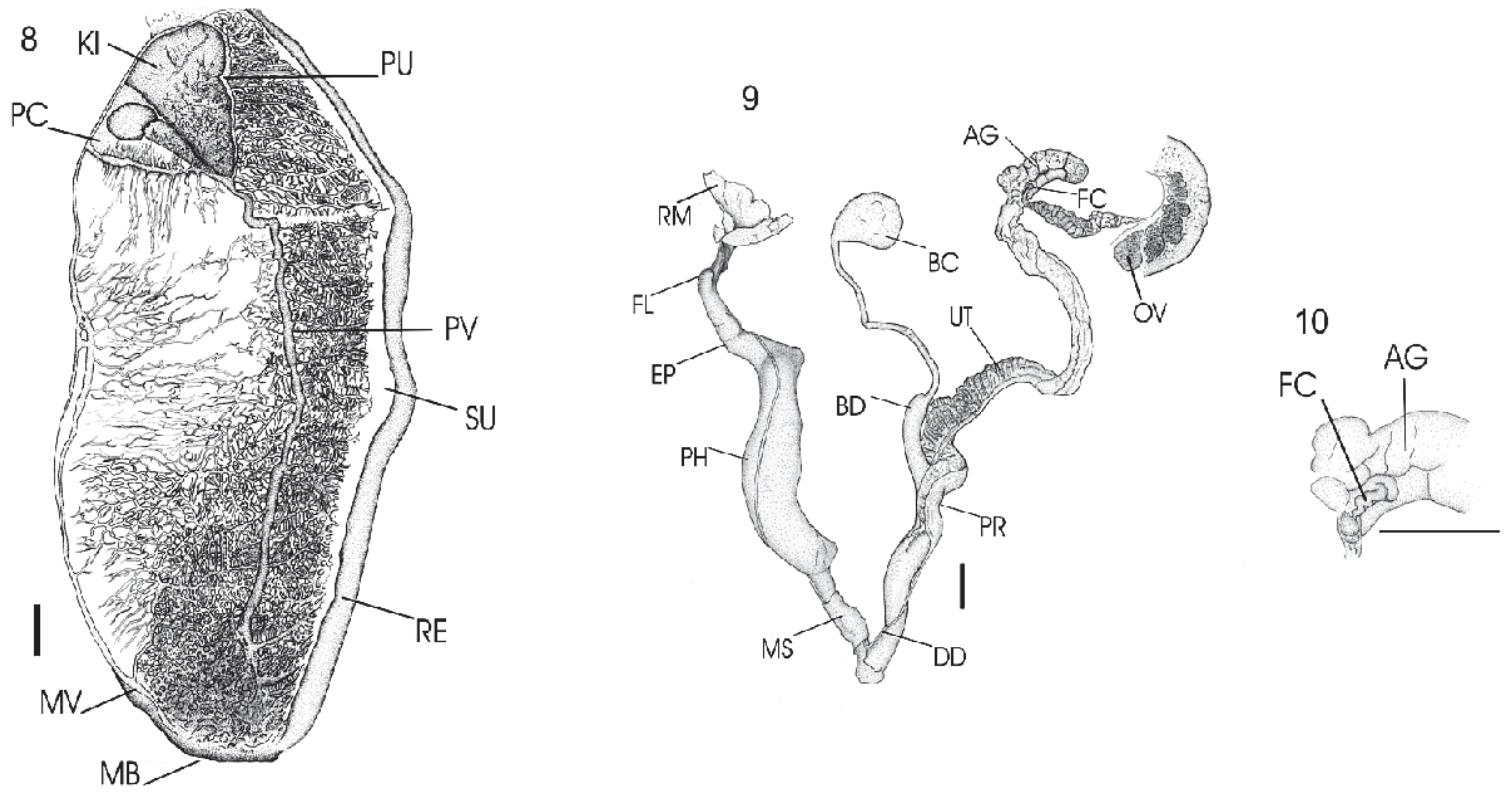

Figs. 8-10. Thaumastus (Thaumastus) lundi sp. nov, paratype, MNRJ 8095. 8, roof of palial cavity. 9, 10, reproductive system (complete and detail) (AG, albumen gland; BC, bursa copulatrix; $\mathrm{BD}$, bursa duct; DD, deferent duct; EP, epiphallus; FC, fertilization complex; FL, flagellum; KI, kidney; MB, mantle border; MS, muscular sheath; MV, marginal vein; OV, ovariotestis; PC, pericardium; PH, phallus; PR, prostate; PU, primary ureter; PV, pulmonary vein; RE, rectum; RM, retractor muscle; SU, secondary ureter; UT, uterus). Scale bars, $5 \mathrm{~mm}$.

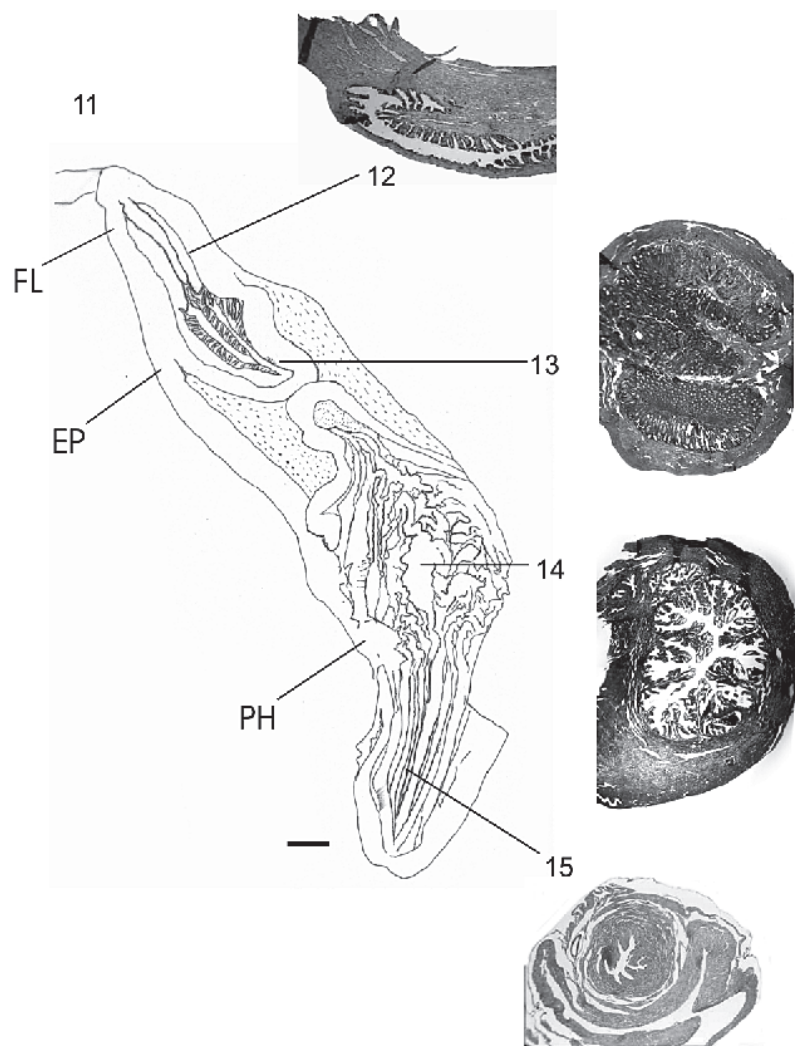

Figs. 11-15. Thaumastus (Thaumastus) lundi sp. nov, paratype MNRJ 9809. 11, penian complex (scale bar, 1mm). 12-15, histological slides (40x): 12, flagellum; 13, epiphallus; 14, apical phallian region; 15, basal phallian region.
Etymology. Named after Danish naturalist Peter Lund who lived and worked for many years in Lagoa Santa region, Minas Gerais State, Brazil.

Type Material. BRAZIL, Minas Gerais: Lagoa Santa Municipality, Lapinha Cave, between crevices of the calcareous stones. Holotype: MNRJ 8092 (h: 77.8, w: 29.3; aperture: ha: 30.1, wa: $16.2 \mathrm{~mm}$ ), J. Becker, H. Schubart \& O. Leoncini col., VIII.1965. Paratypes: from the same locality as the holotype. MNRJ 8093, 1 shell, J. Becker, H. Schubart \& O. Leoncini col., VIII.1965; MNRJ 8094, 1 shell, J. Becker col., XI.1963; MNRJ 8095, 27 shells (13 juv.), 2 jaws, 2 soft parts, 2 roofs of palial cavity, 2 reproductive systems, 16 histological slides of reproductive system; MNRJ 8096, 1 specimen, M.S. Pena \& L. M. A. Azevedo col., II.1998; MNRJ 9807, 10 shells (9 juv.), 1 protoconch (in stub), M. S. Pena \& R. A. F. Cajá col., III.1999; MNRJ 9808, 1 specimen, M. S. Pena col., I.1998; MNRJ 9809, 3 specimens, 2 shells, 4 jaws, 2 radulas (one in alcohol and other in stub), 1 reproductive system, 22 histological slides of penian complex, M. S. Pena col., XII.2000; ZMU 2961, 1 shell; MZSP 39386, 1 shell. Pedro Leopoldo Municipality, "Grande Abrigo da Lapa Vermelha" "Emperaire" (= Lapa Vermelha IV, Sector 22-23D, 10.50-11.00m), MNRJ 4179, 1 shell, F. L. Souza-Cunha col., VIII.1976; Lapa Vermelha I, MNRJ 9983, 1 fragmented shell (complete body whorl), F. L. Souza-Cunha col., VIII.1976.

\section{DISCUSSION}

Thaumastus (Thaumastus) lundi sp. nov. and T. (T.) taunaisii are similar by having the shell with elongated shape, standard of striae in the protoconch, brownyellowish color and thickened peristome. Regarding the reproductive system, they share the same course of deferent duct over the phallus muscular sheath and distal attachment of phallus retractor muscle.

Thaumastus (Thaumastus) taunaisii differs by having smaller dimensions (h: 65.55-75.68, w: 28-32.38mm) 
and oval aperture in the shell, more teeth in the row of radula (46), and fewer plates on the jaw (10-11). Concerning the reproductive system, T. (T.) taunaisii differs by the number of follicle groups (7), unilateral abrupt constriction in the middle of the bursa duct, the emergence of the deferent duct on the same level as the bifurcation between the free oviduct and the bursa duct, and a wide loop formed by deferent duct under the phallus muscular sheath.

Acknowledgments. To M.Sc. Julio C. Monteiro (Malacologia, Departamento de Invertebrados, Museu Nacional) by the drawings of reproductive system and roof of palial cavity and M.Sc. Alexandre Dias Pimenta (Instituto de Biologia, Universidade Federal do Rio de Janeiro) for the help in arranging the plates. Thanks also to the technician Rubens Miranda (Laboratório de Histologia, ICBC / PUC-MG) for the histological preparation.

\section{REFERENCES}

Barros, H. M.; Coelho, A. C. S. \& Salgado, N. C. 1991. Superfamília Bulimuloidea do Brasil. Bulimulidae: Thaumastus (Thaumastus) magnificus (Grateloup, 1839) (Mollusca, Gastropoda, Pulmonata). Boletim do Museu Nacional, N.S., Zoologia, (348):1-18.

Breure, A. S. H. 1979. Systematics, phylogeny and zoogeography of Bulimulinae (Mollusca, Gastropoda), II. Zoologishe Verhandelingen, (168):3-215.

Jurberg, P.; Barros, H. M.; Gomes, L. A. L \& Coelho, A. C. S. 1988. Superfamília Bulimuloidea do Brasil. Bulimulidae:
Thaumastus (Thaumastus) taunaisii (Férussac, 1822), com dados biológicos e aspectos comportamentais (Mollusca, Gastropoda, Pulmonata). Boletim do Museu Nacional, N. S., Zoologia, (358):1-47.

Jurberg, P.; Gomes, L. A. L.; Barros, H. M. \& Coelho, A. C. S. 1979. Superfamília Bulimuloidea do Brasil. Bulimulidae: Thaumastus (Thaumastus) achilles (Pfeiffer, 1852) (Mollusca, Gastropoda, Pulmonata). In: Encontro dos Malacologistas Brasileiros, $5^{\circ}$, Mossoró. Anais... Porto Alegre, FZB. p. 2132. (Publicações Avulsas, FZB, 4).

Küppers, H. 1979. Atlas de los colores. Barcelona, Blume. $161 \mathrm{p}$.

Pena, M. S; Coelho, A. C. S. \& Salgado, N. C. 1996. Bulimuloidea do Brasil. Duas novas espécies de Thaumastus Martens in Albers, 1860 (Mollusca, Gastropoda, Pulmonata). Boletim do Museu Nacional, N. S., Zoologia, (368):1-12.

Salgado, N. C. \& Coelho, A. C. S. 1995. Macroanatomia, microanatomia e histologia do sistema digestivo de Thaumastus (Thaumastus) taunaisii (Férussac, 1822), T.(T.) magnificus (Grateloup, 1839) e T. (T.) achilles (Pfeiffer, 1852) (Mollusca, Gastropoda, Bulimulidae). Boletim do Museu Nacional, N. S., Zoologia, (362):1-19.

Salgado, N. C.; Coelho, A. C. S \& Barros, H. M. 1995. Macroanatomia, microanatomia e histologia do sistema reprodutor de Thaumastus (Thaumastus) taunaisii (Férussac, 1822), T.(T.) magnificus (Grateloup, 1839) e T.(T.) achilles (Pfeiffer, 1852) (Mollusca, Gastropoda, Bulimulidae). Boletim do Museu Nacional, N. S., Zoologia, (358):1-47.

Strebel, H. 1910. Conchologische Mitteilungen aus dem Naturhistorischen Museum in Hamburg. Abhandlugen aus dem Gebiete der Naturwissenschaften, 19(3):1-35.

ZILCH, A. 1960. Euthyneura. In: WenZ, W. Gastropoda. Handbuch der Paläozologie. Berlin, Gebrüder Borntraeger. band 6, teil 2, p. 401-834. 